\title{
A snapshot of substitute early childhood teachers in Sweden and Australia: Differences in training, regulation and quality
}

\section{İsveç ve Avustralya'da vekil okul öncesi öğretmenlerinin durumu: Eğitim, yönetmelik ve kalitedeki farkllıklar}

\author{
Rauni Karlsson ${ }^{1}$, Airi Bigsten ${ }^{2}$, Susanne Garvis ${ }^{3}$
}

\section{Article History \\ Received : 16 October 2017 \\ Revised : 21 November 2017 \\ Accepted : 08 December 2017 \\ Online : 09 December 2017}

Article Type

Original Article

\section{Makale Geçmişi \\ Geliş : 16 Ekim 2017 \\ Düzeltme : 21 Kasım 2017 \\ Kabul : 08 Aralık 2017 \\ Çevrimiçi : 09 Aralık 2017}

Makale Türü

Özgün Makale

\begin{abstract}
Substitute teachers play an important role within early childhood education. They are expected to take on the roles and responsibilities of working with children and parents when the regular teacher is away. While they have an important role, they have received little attention within the research literature. This study helps to fill this void by providing a snapshot of early childhood substitute teachers in Sweden and Australia. A comparative analysis was used to find similarities and differences across the two contexts. Findings show that while the role may be similar, there are many differences in the training, regulation and quality assessment of early childhood substitute teachers. These differences are important for investigation to help improve the quality within early childhood education.
\end{abstract}

Keywords: Substitute teachers, early childhood, regulation, registration

Öz: Vekil öğretmenlerin erken çocukluk eğitiminde önemli bir yeri vardır. Vekil öğretmenlerin sınıfın ası öğretmeni okulda olmadığında aileler ve çocuklar ile çalışma sorumluluklarını ve rollerini almaları beklenir. Böyle önemli bir rolleri varken alan yazında vekil öğretmenlere ilişkin yapılan çalışmaların sınırlı olduğu görülmektedir. Bu çalışma ile İsveç ve Avustralya'da vekil okul öncesi öğretmenlerinin durumu açıklanarak alan yazındaki bu boşluğun doldurulması sağlanacaktır. İki bağlamda yer alan farklılıklar ve benzerlikleri ortaya çıkarmak için karşılaștırmalı analiz kullanılmıştır. Bulgular vekil okul öncesi öğretmenlerinin benzer rollere sahip olmalarına karşın, eğitim, yönetmelik ve kalite değerlendirmeleri açısından farklılıklar olduğunu göstermiştir. $\mathrm{Bu}$ farklılıkların incelenmesi erken çocukluk eğitiminde kaliteyi artırmaya yardımcı olacağı için önemlidir.

Anahtar Kelimeler: Vekil öğretmenler, erken çocukluk, yönetmelik, 


\section{INTRODUCTION}

The journey of becoming an early childhood teacher involves the mastery of particular knowledge and skills that form the base for quality practice (Ryan \& Grieshaber, 2005). The literature suggests early childhood teacher education programs strongly influence the way that future early childhood teachers impact the nature and quality of young children's interactions and experiences in early childhood settings (Ackerman, 2005). In guiding young children's development and learning, pre-service teachers need to learn several broad areas of knowledge including: early childhood foundations; domain-specific curriculum content; and issues related to working with families and working with children from diverse linguistic and cultural backgrounds (Copple \& Bredekamp, 2009; Lobman, Ryan \& McLaughlin, 2005). The role of an early childhood teacher is therefore complex.

While some early childhood teachers will choose to be employed full-time or part-time, other teachers in Australia will choose to become substitute or supply teachers but in Sweden a substitute teacher does not need any kind of early childhood teacher education. A substitute or a supply teacher replaces the classroom early childhood teacher when they are away or sick. It is a temporary position that may last hours, a day or more. While it is important position for the daily operations within a school, only a handful of studies have investigated substitute teachers. Most of this has been based within the economic perspective of labour supply (Gershenson, 2012), the psychological perspective of coping (Vorell, 2011) and the professional identity perspective of the teacher (Driedger Enns, 2014), often conducted with primary and secondary level substitute teachers. There is little research within the academic literature however about early childhood substitute teachers. We have also not been able to find research literature that provides details about the training, regulations and controls of early childhood substitute teachers in different countries. This paper helps to fill this void by providing details of substitute early childhood teachers in Sweden and Australia. The intention is to share both contexts, as well as to explore differences in the training, regulations and the quality associated with substitute teachers.

\section{Focus of the article}

By going beyond, one's own context, researchers are able to move beyond the familiar to see with a kind of 'peripheral vision' (Bateson, 1994). It also allows researchers to look over their backyards to see what their neighbours are doing (Grossman \& McDonald, 2008). Sweden and 
Australia share many characteristics in early childhood education despite being so far from each other. Both have qualified preschool staff and assistants working with young children. Both countries also have a national curriculum and universal access for children. The countries however come from different cultural backgrounds with difference governance and management strategies implemented within early childhood education and care. This study allows the researchers to look beyond their own contexts to see what others are doing. This study will explore the similarities and differences within the Swedish and Australian context for substitute early childhood teachers. A brief history of policy around substitute early childhood teachers in both countries will also be given.

A description of the Swedish context will be given first, followed by a description of the Australian context. The article will conclude with a discussion exploring the similarities and differences.

\section{The Swedish context}

Preschool in Sweden accommodates children from one to five years of age. Preschool in Sweden is a separate type of school and is governed by the Education Act (SFS 2010: 800) and curriculum (Skolverket, 2016). The Education Act has a specific chapter dedicated to the quality of preschools. The Education Act describes the purpose of education and preschool should be offered to all children. Children should be offered an educational activity in a holistic approach including care, development and learning. The preschool curriculum, Lpfö98 (revised in 2010), also states specific goals and guidelines for preschool work. Within each of the municipalities, the director of the preschool is the legal representative, responsible to ensure stated goals and guidelines for preschool work. Operations in the nursery should ensure and support that 1) quality, 2) equivalence, and 3) anchoring (Skolverket, 2015a) are fulfilled. Quality responsibility means ensuring that the education is conducted on the basis of national goals, requirements and guidelines, and that staff are given the opportunity to conduct a systematic quality work. This means that the municipality has the ultimate responsibility to ensure that the resources are available for the preschool. An important point of the revised curriculum is that the preschool teacher is responsible for the pedagogical work. In addition to quality aspects, the municipality is required to follow the requirements of the school law that the education should be equivalent regardless of where in the country it is conducted. The third area, anchoring, means that education in preschool should be based on scientific knowledge and proven experience. For this to be possible, the staff need continuously be provided courses 
to improve their knowledge and pedagogical skills.

The Education Act also stipulates that training and resources should be consistent, regardless of location in Sweden. All municipalities are also entitled to provide free universal preschool from 3 years of age for 15 hours a week. The introduction of universal preschool is based on the idea of creating a 'level playing field' so that all children have an equal educational foundation regardless of social factors (Prop. 2004/05: 11). In addition, all children one year of age, whose parents are unemployed or on parental leave, the right to attend preschool at least three hours per day or 15 hours a week (SFS 2010: 800).

According to the preschool curriculum, skill development is decided jointly between the director and preschool staff. Staff in schools also task on a supervisory responsibility under the Parental Code (SFS 1949: 381). This means that staff takes over parental supervision responsibilities. In addition, staff is required to report child abuse to social services in the municipality as part of the Social Services Act.

To start working in preschool educational activities (including substitute teachers and preservice teachers), a criminal check is required (Prop. 2012/13: 194). It is part of the assessment base for whether a person is suitable for work in preschool. A person who has a criminal record should not be employed. However, there are some exceptions. The Government has decided that the requirements of police checks do not apply to those who already work in the activities covered by the legislation, or who have had employment, assignment, training or the like in the school system and within a year are offered a renewed opportunity to work in the same business. The criminal checks show if the person has committed child related crimes or general things such as burglary or violence.

To become a preschool teacher in Sweden, students must study pre-school teacher education for 3.5 years. Programs vary across universities. At the university in the study, the preschool teacher program during the first three years is given on the first cycle level. The last semester in preschool training is at second cycle level, which leads to Bachelor of Arts in Preschool Education diploma. In some localities however, there are now advanced courses for the last semester of study.

Sick leave among preschool staff has increased significantly with stress-related ailments (AFA, 2015). Statistics show that the number of stress-related diagnoses have doubled since 2009. 
According to the Labour Force Survey (SCB) in 2012/2013, 62,300 people were employed as preschool teachers. It is a general issue that has been debated in the daily press as in Dagens Nyheter's review (published 2015-11-03) also showed that 70 percent of municipalities current lack and will have a shortage of preschool teachers in the future. Currently 53 percent of municipalities have problems filling preschool teacher positions, hiring untrained staff regardless of studies in upper secondary school to fill shortages. Göteborgs Posten (Björk, published 2015-10-19) reports that 7 out of 10 districts in Gothenburg ( $2^{\text {nd }}$ largest city in Sweden) also have a lack of substitute preschool teachers. Public debate has in recent years discussed the problems with a lack of substitute preschool teachers and how the problem with persist in the future.

The requirements for substitute preschool teachers differ across regions. In rural communities, with long distances between kindergartens, additional requirements are to have completed a child and recreational program at upper secondary level, as well as a driving license and car (Arvika Kommun, 2016). In Luleå (Luleå Kommun, 2016) prospective short-term substitute teachers must implement an interactive introductory program. Furthermore, they must undergo a one-day training program in a kindergarten. In the municipality of Norrköping (Sveriges Kommuner och Landsting, 2015) it is different again with a focus on continuity. Their recruitment is for 25 young people aged between 20-25 years who are offered a one-year contract where $50 \%$ of the time is spent in preschool. The remaining $50 \%$ of employment is offered in secondary education, with content from the child and recreation program. The aim is to have young people continue their education and to become full time employees in preschools. The municipality of Norrköping sees this as a step towards meeting the future need to recruit staff for preschool. In Gothenburg there are 11 staffing units where short-term substitute preschool teachers can be booked. It is desirable that substitute teacher have some work experience related to children and have a diploma from a Child and Recreation program, for example at the upper secondary school or have taken a class related to working with children. What is clear across the Swedish context is that there are no formal requirements of qualifications for the training of employment of substitute preschool teachers. One possibility could be that the quality of short-term substitute teachers is not a major contributor to preschool quality in daily operations. Rather the substitute teacher is seen as extra hands to replace the staff member who is absent. Depending on the availability of substitute teachers and their experience of having worked in preschool, they can be seen either as a couple of extra hands or as a contribution to the educational activity. 


\section{The Australian context}

In 2012, the Australian government implemented the National Quality Framework for early childhood education. The Framework is designed to raise quality and drive continuous improvement and consistency in Australian education and care services. A particular focus has been made within the framework on having degree qualified early childhood teachers working with young children. It is acknowledged that qualified teachers provide the most beneficial learning for children within early childhood programmes. The National Quality Framework acknowledges that higher qualified educators improve outcomes for children because they have a greater understanding of child development, health and safety issues. Qualified educators are also better equipped to lead activities that inspire children and help them learn and develop.

As of November 2015, there are 36,400 early childhood teachers in Australia (Australian Government Job Outlook, 2016). Currently $45.2 \%$ of early childhood teachers have a bachelor degree, with many students also studying to become future teachers. Qualified early childhood teachers are required in all Australian long day care centres and kindergartens. Qualified early childhood teachers are linked to the universal access agreement for all 3 and half year-old children within Australia (Australian Children's Education and Care Quality Authority, 2015) who require access to a 15 hour a week education programme delivered by a qualified early childhood teacher.

An early childhood teacher is defined as "person with an approved early childhood teaching qualification. Centre-based services are required to have access to or attendance of an early childhood teacher" (Australian Children's Education and Care Quality Authority, 2015, p. 1). The qualifications of early childhood teachers are assessed by the Australian Children's Education and Care Quality Authority (known as ACECQA). They are also registered with different state teacher registration bodies as part of the Australian Institute for Teaching and School Leadership. To continue registration, teachers must provide evidence of professional learning. Teachers must adhere to the Australian Professional Standards for Teachers (Australian Institute for Teaching and School Leadership, 2013, p. 4). For example, in the state of New South Wales, all early childhood teachers must hold a teaching qualification approved by ACECQA as well as provide evidence of implementing and assessing the Early Years Learning Framework. 
The monitoring of qualified early childhood teachers also extends to supply or relief teachers who are available when the usual early childhood teacher is away. The early childhood relief teacher must also be qualified within early childhood teaching and be registered with the Australian Institute for Teaching and School Leadership. They also undergo regular police checks to ensure early childhood teachers do not have a criminal record. From July 2016, all graduating teachers need to complete a national literacy and numeracy test to ensure teachers have adequate skills. The certification of graduating teachers is conducted by different organizations within each state and territory. Graduating teachers are required to have evidence of how they adhere to each of the professional standards, as well as references about their conduct as a teacher.

\section{So, what can we learn looking across the countries?}

While each of the countries are dedicated to improving the quality of early childhood education and care for young children, they have implemented different standards and ways of working with substitute preschool teachers. Below is a table to demonstrate the major similarities and differences across the countries.

Table 1. Comparisons between Australia and Sweden

\begin{tabular}{lcc}
\hline & Australia & Sweden \\
\hline Universal access for children & $\mathrm{X}$ & $\mathrm{X}$ \\
Free hours for children to attend preschool & $\mathrm{X}$ & $\mathrm{X}$ \\
Specific curriculum for preschool & $\mathrm{X}$ & $\mathrm{X}$ \\
Bachelor qualifications for preschool teachers & $\mathrm{X}$ & $\mathrm{X}$ \\
Bachelor qualifications for substitute teachers & $\mathrm{X}$ & \\
Registration body for substitute teachers & $\mathrm{X}$ & $\mathrm{X}$ \\
Substitute teachers are supervised at a local level & & \\
\hline
\end{tabular}

Many similarities can be found with policy provision in both countries. Both countries provide universal access agreements for young children and have implemented curriculum frameworks for preschools. Both countries have also provided 15 free hours for children to attend preschool as part of the universal access agreements. Both countries also have a Bachelor qualification for preschool teachers, with Sweden having a 3.5-year program and Australia having a 4 year program. The Australian context however has an external agency to review the content of preschool teacher education programs to provide approval.

The biggest differences across the countries is the regulations and organisation of substitute preschool teachers. In Australia, substitute preschool teachers are required to have a Bachelor early childhood teacher qualification and be registered with a teacher registration body 
depending on the state. Preschool teachers are also required to provide evidence of how they implement and assess the relevant curriculum. The criterion is implemented by external government agencies to ensure standards across the early childhood sector. The preschool teacher also has the legal responsibility for children in their care. Alternatively, in Sweden substitute preschool teachers do not require a Bachelor level qualification, however in many of the regions experience with child and recreation is demanded. All substitute teachers require a police check with no criminal record showing. The employment of substitute teachers is administered at a local level, with each municipality choosing who to employ and the level of skills required. Rather than being the teacher in charge for the day, the substitute is positioned as a 'set of extra hands' to help for the day, working with the other teachers. The local level of organisation allows for different criteria depending on the needs of the community. For example, substitutes in remote areas are required to have a car.

The difference in the positioning of substitute teachers may be because of the structure of how preschool teachers work in Australia and Sweden. In the Australian context, preschool teachers are often in isolation. When the preschool teacher is absent the substitute teacher takes on all of the responsibility with the early childhood classroom. In the Swedish context, preschool teachers and substitute teacher work together as a team, where sometimes two or three preschool teachers could be present with a group of children. If a preschool teacher is away, the substitute does not take on the major roles of supervision or responsibility and becomes an "assistant"/ extra hands to help.

Another major consideration is the relationships and ways of working between central and local agencies. In Sweden income tax is paid to the municipality, with only higher income earners paying income tax to the national government. Municipalities have greater control over the services they provide for local residents and organise structure based on need. As such, preschools are organised within the municipality. Alternatively, in Australia where income tax is paid on a national level, national and state government organisations usually administer services and create levels of control. The belief is that a state or national government organisation will provide consistency across the sector. Preschool for example is administered at the national and state level. The requirements for preschool teachers is highly regulated and controlled, often working within a neo-liberal design. 


\section{Thinking about substitute teachers in the future?}

While both countries have policies directed towards quality within preschools and provide universal access for children, the differences around the organisation and regulation of substitute teachers also raises a number of questions for consideration. Firstly, what types of skills and knowledge do substitute teachers actually require? In the Australian context it is acknowledged that the skills are same as regular teachers. In Sweden, the municipality decides, however some experience with children is needed, as in Luleå the one-day training program in a kindergarten, in Norrköping a one-year-introduction-program for young people, or just a diploma from child and recreational program at upper secondary level, as well as a driving license and car. Both countries however do not provide specialist training for substitute teachers. For consideration is the need to understand the specific skills that substitute teachers need. Often, they enter into contexts they may be unfamiliar with and are expected to have conversations with staff and children they do not have a relationship with. The substitute teacher will also leave at the end of the day, meaning that any relationship that was established are soon ended. Does this mean the substitute teachers require different training given that their work is different? Is it possible to develop a set of knowledges and skills that substitute teacher require?

Also, consideration is needed about the relationship between preschool quality and substitute teachers. How can organisations ensure that preschool quality remains the same when regular teachers are away and a substitute teacher take their place? Is it reasonable if quality is not considered on those days, where having a substitute teacher in place to keep the preschool open is more important? Such questions are important for organisations in either country to consider.

Another importance consideration within the discussion of substitute teachers are the voices of families and young children. What do they think about substitute teachers? What skills and knowledge do they think a substitute teacher should have?

What is clear is that there is limited research in this area. When searching in online databases for substitute teachers, numerous articles appear for primary and secondary level teachers. The field of early childhood however appears under-researched, with few studies providing an empirical evidence. Future research is needed in this area to develop new ways of understanding substitute teachers within the field of early childhood education. Questions to be asked regarding substitute teachers are for example; where to find short-term substitute teachers, who 
applies for them, is it possible to get the same teacher used before, and what are these substitute teachers' responsibilities?

\section{CONCLUSION}

This paper has shown the similarities and differences in how countries implement and organise substitute preschool teachers. While Australia has taken a more national and state regulatory role, Sweden has a more localised approach when working with substitute teachers. While the paper is not intended to show that one system is better than the other, it has been able to highlight the differences in how both countries implement an often-forgotten area of early childhood education, substitute teachers. As yet few studies have specifically focused on substitute teachers within the early childhood field. It is hoped that this paper will help fill this void and create a pathway for future consideration about preschool substitute teachers working with young children.

\section{REFERENCES}

Ackerman, D. J. (2005). Getting Teachers from Here to There: Examining Issues Related to an Early Care and Education Teacher Policy. Early Childhood Research and Practice, 7(1). Retrieved 2 March 2012 from Available: http://ercp.uiuc.edu/v7n1/ackerman.htm

AFA försäkringar. (2015). Analys och statistik. Retrieved 13 December 2015 from https://www.afaforsakring.se/globalassets/forebyggande/analys-och-statistik/f6345psykiska-diagnoser.pdf

Arvika Kommun. (2016). Jobba som Kortidsvikare. http://www.arvika.se/naringslivocharbete/arbetsmarknad/jobbasomkorttidsvikarie.4.39 4659b511f7f653d1d800019237.html (hämtad 2016-06-07).

Australian Children's Education and Care Quality Authority. (2015). Higher qualifications. Accessed 14 April 2016 from http://www.acecqa.gov.au/Higher-qualifications

Australian Institute for Teaching and School Leadership. (2013). Australian Professional Standards for Teachers. Accessed 14 April 2016 from http://www.aitsl.edu.au/australian-professional-standards-for-teachers

Björk, E. (2015 October 19th). Sju av tio har brist på timvikarier. Göteborgs Posten. Retrieved from gp.se

Copple, C. \& Bredekamp, S. (Eds.). (2009). Developmentally Appropriate Practice in Early Childhood Programs Serving Children from Birth through Age 8 (3rd ed.). Washington, D.C.: National Association for the Education of Young Children.

Dagens Nyheter. (2015). Stor brist när lärare flyr förskolorna. http://www.dn.se/nyheter/sverige/stor-brist-nar-larare-flyr-forskolorna/ (Hämtad 15$\underline{11-03) .}$ 
Driedger Enns, L. (2014). Relational identity making on the professional landscape as a substitute teacher: Interruptions and continuities. Teacher Education Quarterly, 41(3), 87-103.

Eriksson, A. (2015). Förskollärarens ansvar: från självpåtaget till pålagt och delvis legitimerat. Pedagogisk Forskning $i$ Sverige årg $20 \mathrm{nr}$ 1-2 2015 issn 1401-6788

Gershenson, S. (2012). How do substitute teachers substitute? An empirical study of substituteteacher labor supply. Economics of Education Review, 31(4), 410-430. doi:10.1016/j.econedurev.2011.12.006

Göteborgs Stad. (2016a). Bemanningsenheter._Retrieved 29 September 2016 from http://goteborg.se/wps/portal/invanare/jobb/bemanningspooler/!ut/p/z1/hY9Lb8IwEIR C1cO3k0LiXM0qmh5iICaitiXyokWYykP5FhE8OvrcGhPqHubmf1WO6CgANXqqz Xa267VddBSxd 7aH3gi0hg9p4ucZVv9svdZsvF1xyO y2oEOOTEQgy8MlT_iOGT1 CgenJXW5G_XQjkdHROtvbk3qyjanw13Pk1M2d0a tHhfxB_GXCkQ56DcqWDRuq hiFL-

TxKMU1eMJphgjEcFyAzL2f8MPYXbfnKDShHJ3Lk2LnrPRTDMDDTdaYm1hNc muKeU3mnkt-2YjL5AXMSQ5E!/dz/d5/L2dBISEvZ0FBIS9nQSEh/ (hämtad 201606-07).

Göteborgs Stad. (2016b). Bemanningsenhet Majorna - Linné. Retrieved 29 September 2016 from

http://goteborg.se/wps/portal/enheter/bemanningsenheter/bemanningsenhetmajornalin ne/!ut/p/z1/04 Sj9CPykssy0xPLMnMz0vMAfljo8ziQw0NAi2cDB0NLPyCTA08 fw MvM3Cwowd3c31wwkpiAJKG-

AAjgb6BbmhigB6GKAx/dz/d5/L2dBISEvZ0FBIS9nQSEh/\#htoc-14 (hämtad 201606-07).

Lobman, C., Ryan, S., \& McLaughlin, J. (2005). Reconstructing teacher education to prepare qualified preschool teachers: Les- sons from New Jersey. Early Childhood Research and Practice, 7(2). Retrived 2 June 2016 from http://ecrp.uiuc.edu/v7n2/lobman.html

Luleå Kommun. (2016). Kompetensförsörjningsplan 2016. Barn- och utbildningsförvaltningen. $\quad$ Retrieved $29 \quad$ September 2016 from http://www.lulea.se/download/18.4f85d6521506cf2358e5b0/1444994692701/Kompet ensf\%C3\%B6rs\%C3\%B6rjningsplan+BUF+2016.pdf (hämtad 2016-06-07).

Prop. (2012/13). Stärkt skydd för barn mot sexuella övergrepp. Retrieved 2 June 2016 from https://data.riksdagen.se/fil/90B754B3-DA28-4CCC-AD1F-78F306803CCF

Prop. (2004/05:11) Kvalitet i förskolan. Riksdagstryck.

Ryan, S., \& Grieshaber, S. (2005). Shifting from developmental to postmodern practices in early childhood teacher education. Journal of Teacher Education, 56(1), 34-45.

SFS (2010:800). Skollag. Stockholm: Utbildningsdepartementet. Retrieved 29 September 2016 from

http://www.riksdagen.se/sv/Dokument-

Lagar/Lagar/Svenskforfattningssamling/Skollag-2010800_sfs-2010800/?bet=2010:800\#K1 
SFS (1949:381). Föräldrabalken. Stockholm: Justitiedepartementet L2. Retrieved 29 September 2016 from https:/www.riksdagen.se/sv/DokumentLagar/Lagar/Svenskforfattningssamling/Foraldrabalk-1949381_sfs-1949-381/\#K6

Skolverket. (2015a). Huvudmannens ansvar. Retrieved 13 November 2015 from http://www.skolverket.se/skolutveckling/kvalitetsarbete/huvudmannens-systematiskakvalitetsarbete/huvudmannens-ansvar

Skolverket.( 2015b). Juridisk vägledning. Mer om registerkontroll av personal. Retrieved 3 June $2016 \quad$ from http://www.skolverket.se/polopoly fs/1.162662!/Menu/article/attachment/Registerkon troll personal reviderat 20150914.pdf (hämtad 2016-06-03).

Skolverket, (2015c). Uppdrag om prognos över behovet av olika lärarkategorier. Redovisning av uppdrag om prognos över behovet av olika lärarkategorier. (U2014/4128/S). Retrieved 29 September 2016 from_http://www.skolverket.se/omskolverket/publikationer/visa-enskild-

publikation? xurl_http $\% 3 \mathrm{~A} \% 2 \mathrm{~F} \% 2 \mathrm{Fwww}$.skolverket.se $\% 2 \mathrm{Fwtpub} \% 2 \mathrm{Fws} \% 2 \mathrm{Fskol}$ bok $\% 2$ Fwpubext $\% 2$ Ftrycksak $\% 2$ FBlob $\% 2$ Fpdf3472.pdf $\% 3 F k \% 3 \mathrm{D} 3472$

Skolverket. (2010). Läroplan för förskolan, Lpfö 98, reviderad 2010. Stockholm: Fritzes

Skolverket. (2016). Läroplan för förskolan, Lpfö 98, reviderad 2016. Retrieved 29 September from: $\quad$ http://www.skolverket.se/om-skolverket/publikationer/visa-enskildpublikation? xurl $=$ http $\% 3 \mathrm{~A} \% 2 \mathrm{~F} \% 2 \mathrm{Fwww}$.skolverket.se $\% 2$ Fwtpub $\% 2 \mathrm{Fws} \% 2 \mathrm{Fskol}$ bok $\% 2$ Fwpubext $\% 2$ Ftrycksak $\% 2$ FRecord $\% 3 F k \% 3 D 2442$

Sveriges Kommuner och Landsting. (2015) Arbetslivsintroduktion i förskolan med BAL 131. Ett lärande exempel från Norrköping. Retrieved 29 September 2016 from http://webbutik.skl.se/bilder/artiklar/pdf/7585-255-3.pdf

Vorell, M. (2011). A qualitative analysis of the coping strategies of substitute teachers. Alberta Journal of Educational Research, 57(4), 479-497. 